\title{
A New Cytotoxicity Assay for Brevetoxins Using Fluorescence Microscopy
}

\section{Jennifer R. McCall *, Elizabeth A. Elliott and Andrea J. Bourdelais}

UNCW Center for Marine Science, 5600 Marvin K Moss Lane, Wilmington, NC 28409, USA; E-Mails: elliotte@uncw.edu (E.A.E.); bourdelaisa@uncw.edu (A.J.B.)

* Author to whom correspondence should be addressed; E-Mail: mccalljr@uncw.edu; Tel.: +1-910-962-2081; Fax: +1-910-962-2410.

Received: 1 August 2014; in revised form: 1 September 2014 / Accepted: 4 September 2014 / Published: 23 September 2014

\begin{abstract}
Brevetoxins are a family of ladder-framed polyether toxins produced during blooms of the marine dinoflagellate, Karenia brevis. Consumption of shellfish or finfish exposed to brevetoxins can lead to the development of neurotoxic shellfish poisoning. The toxic effects of brevetoxins are believed to be due to the activation of voltage-sensitive sodium channels in cell membranes. The traditional cytotoxicity assay for detection of brevetoxins uses the Neuro-2A cell line, which must first be treated with the neurotoxins, ouabain and veratridine, in order to become sensitive to brevetoxins. In this study, we demonstrate several drawbacks of the Neuro-2A assay, which include variability for the $\mathrm{EC}_{50}$ values for brevetoxin and non-linear triphasic dose response curves. Ouabain/ veratridine-treated Neuro-2A cells do not show a typical sigmoidal dose response curve in response to brevetoxin, but rather, have a polynomial shaped curve, which makes calculating $\mathrm{EC}_{50}$ values highly variable. We describe a new fluorescence live cell imaging model, which allows for accurate calculation of cytotoxicity via nuclear staining and additional measurement of other viability parameters depending on which aspect of the cell is stained. In addition, the SJCRH30 cell line shows promise as an alternative to Neuro-2A cells for testing brevetoxins without the need for ouabain and veratridine.
\end{abstract}

Keywords: brevetoxins; cytotoxicity assay; triphasic response; hormesis; Neuro-2A; SJCRH30 


\section{Introduction}

Brevetoxins (PbTxs) are a family of ladder frame polyether neurotoxins produced during blooms of the marine dinoflagellate, Karenia brevis [1]. In the United States, K. brevis blooms are frequent, nearly annual occurrences off the coast of Florida, but also occur in North Carolina and other areas in the Gulf of Mexico. The PbTxs produced during these blooms are potent neurotoxins that are known to cause massive fish kills and a large number of mortalities in seabirds, sea turtles and marine mammals [2-5]. The toxic effects of PbTxs are due to binding to and persistent activation of voltage sensitive sodium channels (VSSCs) [6-8]. Humans can become exposed to PbTxs if they consume contaminated shellfish or finfish, which may cause the development neurotoxic shellfish poisoning (NSP), or exposure can occur through sea spray, which may cause respiratory dysfunction in beach visitors. Symptoms of NSP include gastroenteritis, sensory abnormalities, cranial nerve dysfunction and other neurotoxic effects. In severe cases, victims may require emergency room treatment to prevent respiratory failure $[9,10]$. The most common symptoms of exposure to aerosolized PbTxs are eye irritation and acute respiratory irritation of both the upper and lower respiratory tracts, including nasal congestion, throat irritation, cough, chest tightness, wheezing and shortness of breath [11]. People who are particularly susceptible, such as asthmatics and those with COPD, may develop more severe symptoms and require hospitalization following exposure to inhaled PbTxs [12,13]. PbTxs are not destroyed by cleaning, cooking or freezing of fish and cannot be detected by taste or smell, making accurate detection of toxins during K. brevis blooms paramount for consumer safety.

The traditional method for detecting the presence of PbTxs in a sample has been the mouse bioassay, which is the official regulatory method in most countries for determining toxin levels. The mouse bioassay is a whole animal test in which an extracted sample is injected into the peritoneal cavity of a mouse and time to death is monitored. Results are reported as mouse units (MU) per $100 \mathrm{~g}$ of shellfish, where one mouse unit is the amount of crude toxin that on average will kill $50 \%$ of mice in $15.5 \mathrm{~h}$ [14]. The current U.S. guidelines limit PbTx concentrations in shellfish to $20 \mathrm{MU}$ per $100 \mathrm{~g}$ of shellfish, where $1 \mathrm{MU}$ is equivalent to $4 \mu \mathrm{g} \mathrm{PbTx}-2$. This is equivalent to $0.8 \mathrm{ppm}$ of PbTx-2 [15]. However, there are several drawbacks to the mouse bioassay for use as a regular screening mechanism for NSP. These include long time requirements (2-24 h to measurable death and then up to seven days of post-injection observations for no toxicity), high cost (\$100 per test), low specificity (any toxic compound in the sample can kill the mouse), low sample throughput, due to labor-intensive requirements, high variability (due to differences in mouse strain, age and weight) and high animal usage (one animal per test) [14-18].

In an effort to move away from the cumbersome and expensive mouse bioassay, a cytotoxicity assay was developed using a mouse neuroblastoma (Neuro-2A) cell line. In the original assay developed for testing saxitoxins and tetrodotoxin, Neuro-2A cells were treated with veratridine (a VSSC activator) and ouabain (a sodium/potassium pump inhibitor), resulting in sodium influx into the cell and subsequent cell death. Saxitoxins and tetrodotoxin could be detected by their ability to prevent cell death, presumably because of binding to and blocking VSSCs, thus inhibiting sodium influx into the cell $[19,20]$. Manger and colleagues expanded this test to PbTxs with the observation that PbTx treatment sped up cell death, likely due to synergistic activity between veratridine and PbTxs, both of which bind to and activate VSSCs [21,22]. The development of this assay has allowed for the 
study of the cytotoxicity of various PbTx analogs and extracts, as well as extracts from other Karenia species [23-27]. Some investigators have found that the Neuro-2A assay is not as sensitive for detecting PbTxs in samples as other assays, such as LC-MS or receptor binding assays [24,28].

A survey of the literature indicates great variability in methods associated with the Neuro-2A cytotoxicity assay. The ouabain concentration was typically $500 \mu \mathrm{M}$, but the veratridine concentration ranged from 5 to $50 \mu \mathrm{M}$. The time from treatment to measurement varied from 12 to $24 \mathrm{~h}$, and cell seeded density ranged 6000-100,000 [19-30]. The most commonly used method for determining cell death was the MTT colorimetric assay for determining cell viability, in which metabolically active cells reduce the MTT tetrazolium compound to form a blue color. More intense color indicates greater cell viability, and high throughput can be achieved by using a multiwell plate format [21]. It was our intent to develop an improved cytotoxicity assay for PbTxs using a human, rather than rodent, cell line with a more direct detection method that counts individual live cells rather than the MTT assay, which only measures cytotoxicity indirectly. In addition, it was our goal to develop a sensitive cytotoxicity assay using a cell line that did not require the use of ouabain and veratridine to pre-sensitize cells to PbTx toxicity, which likely causes unknown side-effects and uncontrolled variability. To that end, we surveyed seven alternative cell lines for sensitivity to ouabain, veratridine and PbTxs. This report describes the development of a new cytotoxicity assay using fluorescence detection of cytotoxicity using a direct measurement of nucleated cells.

\section{Results and Discussion}

\subsection{Cell Line Survey for Brevetoxin Cytotoxicity}

In order to determine alternative cell line candidates for a PbTx cytotoxicity assay, several cell lines were screened in the presence and absence of ouabain $(500 \mu \mathrm{M})$ and veratridine $(25 \mu \mathrm{M})$ for toxicity to $\mathrm{PbTx}-2$. The choices of concentrations were based on previous literature: $500 \mu \mathrm{M}$ of ouabain was the typical concentration used, and $25 \mu \mathrm{M}$ of veratridine was the approximate middle of the range $(5-50 \mu \mathrm{M})$ used [19-30]. Cell lines were chosen in the attempt to find a human alternative to the rodent neuroblastoma (Neuro-2A) cell line and to survey other neural tissue-derived cells to determine if they have greater sensitivity to PbTxs without the use of ouabain and veratridine. Cytotoxicity was measured by staining and counting nuclei with the Image Xpress Micro, which is a live cell imager. As seen in Table 1 and Figure 1, sensitivity to $\mathrm{PbTx}-2$ without ouabain and veratridine was in the micromolar range for all cell lines after $24 \mathrm{~h}$. Sensitivity increased in most cell lines following $48 \mathrm{~h}$ of treatment. EC50 values (Table 1) were calculated from four well replicates in Figure 1.

Table 1. Cell line survey for brevetoxin $2(\mathrm{PbTx}-2)$ cytotoxicity. $\mathrm{EC}_{50}$ values are calculated from the curves generated in Figure 1.

\begin{tabular}{cccccc}
\hline Cell Line & Cell Type & Seeded Density & $\mathbf{2 4} \mathbf{~ h ~ E C ~} \mathbf{5 0}_{\mathbf{0}}$ & $\mathbf{4 8} \mathbf{~ h ~ \mathbf { E C } _ { \mathbf { 5 0 } }}$ & $\mathbf{7 2} \mathbf{~ h ~ E C _ { \mathbf { 5 0 } }}$ \\
\hline B35 & $\begin{array}{c}\text { Rat neuronal } \\
\text { neuroblastoma }\end{array}$ & 5000 & $3.39 \times 10^{-6} \mathrm{M}$ & $6.40 \times 10^{-7} \mathrm{M}$ & $4.57 \times 10^{-7} \mathrm{M}$ \\
\hline B50 & $\begin{array}{c}\text { Rat neuronal } \\
\text { neuroblastoma }\end{array}$ & 5000 & $5.24 \times 10^{-6} \mathrm{M}$ & $2.22 \times 10^{-6} \mathrm{M}$ & $2.70 \times 10^{-6} \mathrm{M}$ \\
\hline
\end{tabular}


Table 1. Cont.

\begin{tabular}{|c|c|c|c|c|c|}
\hline Cell Line & Cell Type & Seeded Density & $24 \mathrm{~h} \mathrm{EC}_{50}$ & $48 \mathrm{~h} \mathrm{EC}_{50}$ & 72 h EC 50 \\
\hline BE(2)-M17 & $\begin{array}{c}\text { Human } \\
\text { neuroblastoma }\end{array}$ & 5000 & $2.60 \times 10^{-6} \mathrm{M}$ & $9.40 \times 10^{-7} \mathrm{M}$ & $8.77 \times 10^{-7} \mathrm{M}$ \\
\hline Neuro-2A & $\begin{array}{c}\text { Mouse neuronal } \\
\text { neuroblastoma }\end{array}$ & 5000 & $3.66 \times 10^{-6} \mathrm{M}$ & $1.94 \times 10^{-6} \mathrm{M}$ & $2.18 \times 10^{-6} \mathrm{M}$ \\
\hline PC-12 & $\begin{array}{c}\text { Rat adrenal } \\
\text { pheochromocytoma }\end{array}$ & 10,000 & $3.60 \times 10^{-6} \mathrm{M}$ & $2.92 \times 10^{-6} \mathrm{M}$ & $2.99 \times 10^{-6} \mathrm{M}$ \\
\hline SH-SY5Y & $\begin{array}{c}\text { Human bone marrow } \\
\text { neuroblastoma }\end{array}$ & 5000 & $2.26 \times 10^{-6} \mathrm{M}$ & $1.14 \times 10^{-6} \mathrm{M}$ & $8.11 \times 10^{-7} \mathrm{M}$ \\
\hline SJCRH30 & $\begin{array}{l}\text { Human muscle } \\
\text { rhabdomyosarcoma }\end{array}$ & 5000 & $1.70 \times 10^{-6} \mathrm{M}$ & $8.61 \times 10^{-7} \mathrm{M}$ & $7.69 \times 10^{-7} \mathrm{M}$ \\
\hline
\end{tabular}

Figure 1. Sigmoidal dose response curves to PbTx-2 from seven cell lines at (A) $24 \mathrm{~h}$, (B) $48 \mathrm{~h}$ and $(\mathbf{C}) 72 \mathrm{~h}$ post-treatment $(n=4)$. Each point represents the mean \pm standard deviation for $n=4$ replicates.
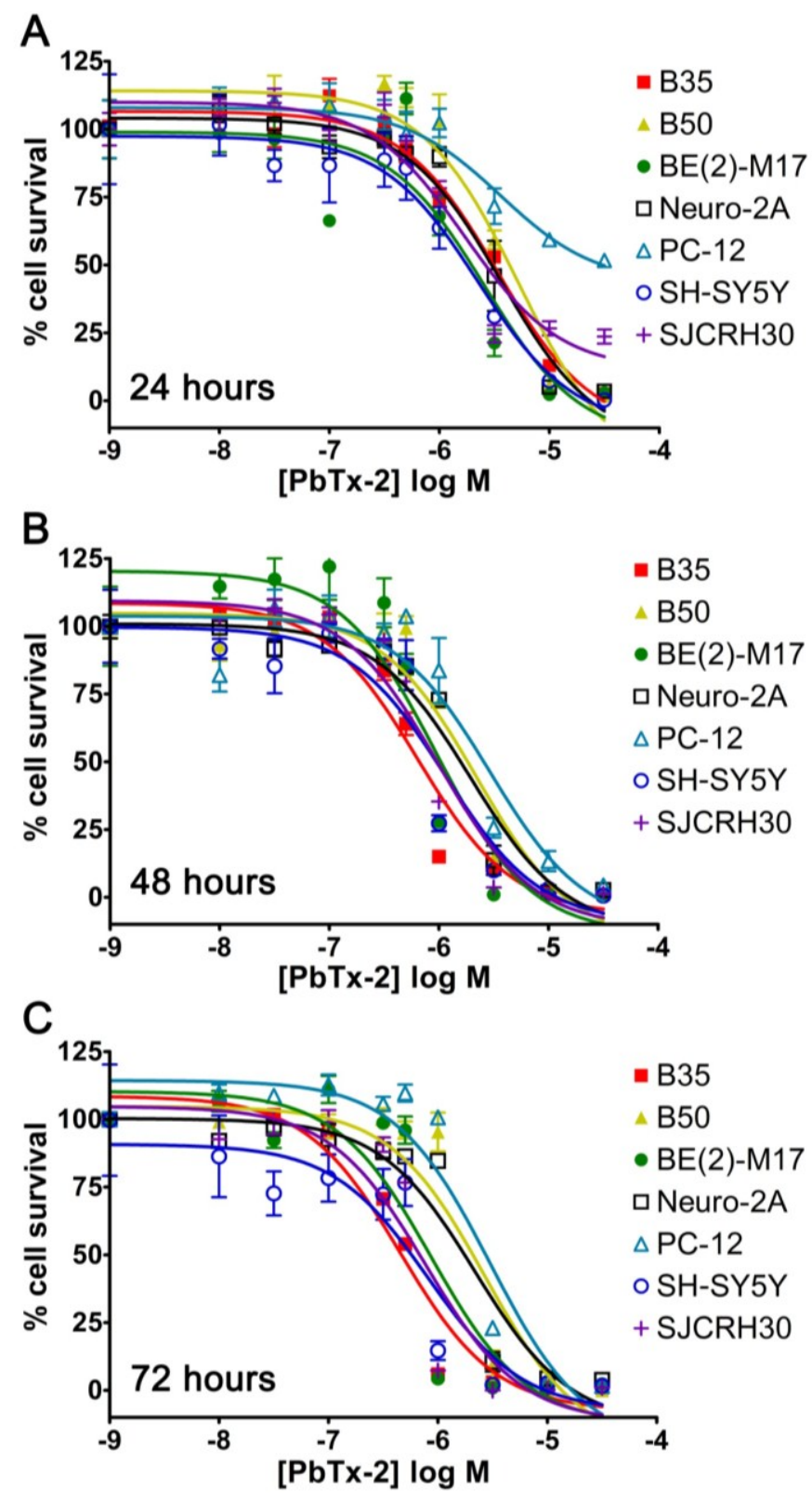
The cell lines greatly differed with co-treatment of ouabain $(500 \mu \mathrm{M})$ and veratridine $(25 \mu \mathrm{M})$. As seen in Table 2, ouabain and veratridine in the ab sence of PbTx-2 resulted in nearly complete cytotoxicity in all human cell lines within $24 \mathrm{~h}$. Ouabain (at all concentrations) and veratridine above $5 \mu \mathrm{M}$ has previously been reported to be cytotoxic in the human embryonic kidney cell line, HEK-293 [31]. For the rodent cell lines, B35, B50 and Neuro-2A, roughly half of all cells died following $24 \mathrm{~h}$ after treatment with ouabain and veratridine and exhibited little to no cell growth over the next $72 \mathrm{~h}$. Nearly all Neuro-2A cells were dead by $72 \mathrm{~h}$ after treatment with ouabain and veratridine (Table 2). Interestingly, the rat PC12 cell line did not show much initial sensitivity to ouabain and veratridine, and it was the only cell line to grow to greater cell numbers after $72 \mathrm{~h}$ with ouabain and veratridine treatment, as compared to $24 \mathrm{~h}$ without ouabain and veratridine (Table 2).

Table 2. Cell line sensitivity to ouabain $(500 \mu \mathrm{M})$ and veratridine $(25 \mu \mathrm{M})$.

\begin{tabular}{ccccc}
\hline Cell Line & $\begin{array}{c}\text { Time } \\
\text { Point }\end{array}$ & $\begin{array}{c}\text { Cell Count without } \\
\text { Ouabain/Veratridine }\end{array}$ & $\begin{array}{c}\text { Cell Count with } \\
\text { Ouabain/Veratridine }\end{array}$ & $\begin{array}{c}\text { Percentage } \\
\text { Knockdown (of 24 h) }\end{array}$ \\
\hline B35 & $24 \mathrm{~h}$ & 199.2 & 105.4 & $47 \%$ \\
B35 & $48 \mathrm{~h}$ & 420.9 & 120.3 & $40 \%$ \\
B35 & $72 \mathrm{~h}$ & 1020.3 & 153.2 & $23 \%$ \\
B50 & $24 \mathrm{~h}$ & 201.6 & 106.9 & $47 \%$ \\
B50 & $48 \mathrm{~h}$ & 541.1 & 122.8 & $39 \%$ \\
B50 & $72 \mathrm{~h}$ & 820.6 & 158.4 & $21 \%$ \\
BE(2)-M17 & $24 \mathrm{~h}$ & 164.3 & 5.5 & $97 \%$ \\
BE(2)-M17 & $48 \mathrm{~h}$ & 296.0 & 3.9 & $98 \%$ \\
BE(2)-M17 & $72 \mathrm{~h}$ & 696.2 & 7.8 & $95 \%$ \\
Neuro-2A & $24 \mathrm{~h}$ & 532.0 & 270.8 & $49 \%$ \\
Neuro-2A & $48 \mathrm{~h}$ & 722.8 & 105.2 & $80 \%$ \\
Neuro-2A & $72 \mathrm{~h}$ & 766.8 & 48.3 & $91 \%$ \\
PC-12 & $24 \mathrm{~h}$ & 334.2 & 275.3 & $18 \%$ \\
PC-12 & $48 \mathrm{~h}$ & 540.1 & 317.4 & $5 \%$ \\
PC-12 & $72 \mathrm{~h}$ & 927.5 & 602.2 & $-80 \%$ \\
SH-SY5Y & $24 \mathrm{~h}$ & 73.5 & 8.2 & $89 \%$ \\
SH-SY5Y & $48 \mathrm{~h}$ & 71.0 & 9.7 & $87 \%$ \\
SH-SY5Y & $72 \mathrm{~h}$ & 62.4 & 2.7 & $96 \%$ \\
\hline SJCRH30 & $24 \mathrm{~h}$ & 208.0 & 1.8 & $99 \%$ \\
SJCRH30 & $48 \mathrm{~h}$ & 306.0 & 0.4 & $100 \%$ \\
SJCRH30 & $72 \mathrm{~h}$ & 570.1 & 0.1 & $100 \%$ \\
\hline
\end{tabular}

Previous studies had stated that ouabain (up to $2 \mathrm{mM}$ ) and veratridine (up to $0.1 \mathrm{mM}$ ) alone were not toxic to Neuro-2A cells [19]. In our present study, dose response curves of ouabain (up to $500 \mu \mathrm{M}$ ) or veratridine (up to $50 \mu \mathrm{M}$ ) alone confirmed little toxicity to Neuro-2A after $24 \mathrm{~h}(80 \%$ and $100 \%$ cell survival, respectively). However, this declines by $48 \mathrm{~h}$ to $52 \%$ and $75 \%$ cell survival for the highest doses of ouabain and veratridine, respectively. When added together, $500 \mu \mathrm{M}$ ouabain and $50 \mu \mathrm{M}$ veratridine yielded $82 \%$ cell survival after $24 \mathrm{~h}$ and $50 \%$ cell survival after $48 \mathrm{~h}$, which is not significantly different from the results obtained with ouabain alone. When only $25 \mu \mathrm{M}$ veratridine were added to $500 \mu \mathrm{M}$ ouabain, cell survival was $79 \%$ after $24 \mathrm{~h}$ and $58 \%$ cell survival after $48 \mathrm{~h}$, 
which was not significantly different from the values obtained with $500 \mu \mathrm{M}$ ouabain and $50 \mu \mathrm{M}$ veratridine or from $500 \mu \mathrm{M}$ ouabain alone.

The three human cell lines surveyed were examined for cell morphology and compared to the Neuro-2A cell line. As shown in Figure 2, SJCRH30 cells were large and spread out, as compared to the smaller BE(2)-M17 and SH-SY5Y cells, which allowed for greater counting efficiency for live cell imaging and allowed for easier measurement and visualization of morphological changes associated with toxin exposure. While all four cell lines were plated at the same density, the SH-SY5Y cells did not grow as well as BE(2)-M17, SJCRH30 or Neuro-2A cells. Therefore, SJCRH30 cells were chosen for further study, because of the increased sensitivity to $\mathrm{PbTx}-2$ at $24 \mathrm{~h}$ and because of the large size, which allows for clear pictures and calculations of the morphological parameters.

Figure 2. Images of (A) Neuro-2A; (B) SJCHR30; (C) SH-SY5Y and (D) BE(2)-M17 cell lines. Cells were stained with Hoechst 33342 nuclear dye (blue) and Tubulin Tracker (green). The scale bar is at $100 \mu \mathrm{m}$.
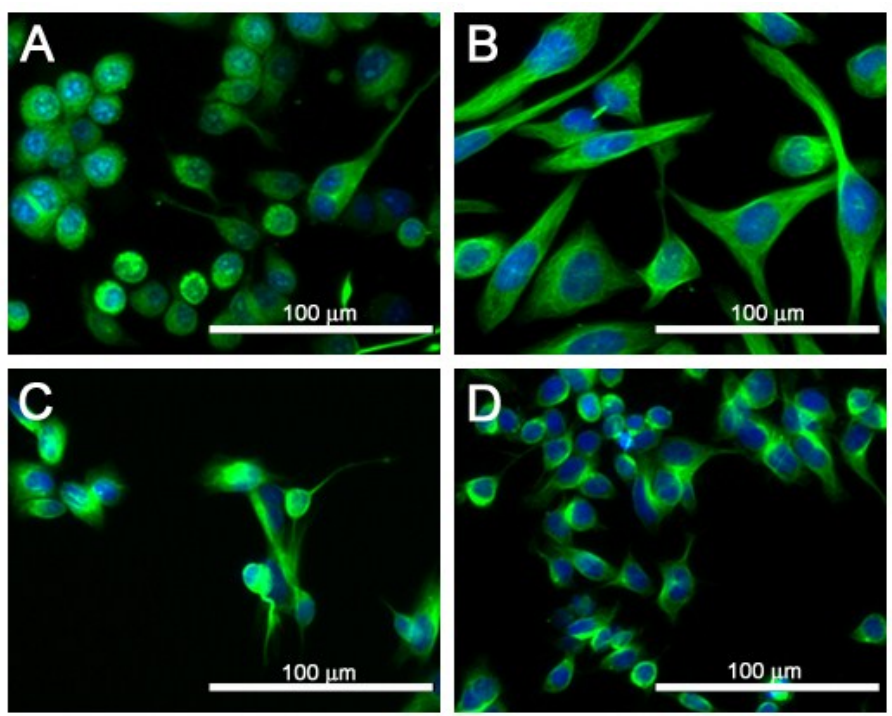

\subsection{Cytotoxicity of PbTx-1 and PbTx-2 to SJCRH30 and Neuro-2A Cell Lines}

To compare the human cell line model (SJCHR30) to the traditional PbTx cytotoxicity model (murine derived Neuro-2A), we performed comparative cytotoxicity experiments with the XTT assay and the nuclear fluorescent stain Hoechst 33342 (H-dye) microscopy assay. EC 50 values were calculated from cytotoxicity curves for each experiment (Tables 3 and 4) and reflect a calculation of at least $n=3$ separate experiments. Two concentrations of veratridine $(25 \mu \mathrm{M}$ and $50 \mu \mathrm{M})$ were used for the Neuro-2A cell line, because of the variability in previous literature. As shown in Tables 3 and 4, SJCRH30 cell lines show greater sensitivity to PbTxs after $48 \mathrm{~h}$ when compared to Neuro-2A cell lines without ouabain and veratridine. As such, we suggest this cell line as a preferable model for cytotoxicity when the goal is to observe the effects of PbTxs in the absence of confounding factors, such as ouabain and veratridine. In addition, there was no significant difference between the H-dye nuclear stain microscopy assay or XTT assay for either SJCHR30 or Neuro-2A cell lines without ouabain and veratridine. 
Table 3. EC 50 values for cytotoxicity of PbTx-1 on SJCRH30 and Neuro-2A cells as measured by the XTT and H-dye assays. * indicates significance from SHCRH30, and \# indicates significance from Neuro-2A (values in the same column).

\begin{tabular}{|c|c|c|c|c|}
\hline Cell Line & H-Dye: 24 h & H-Dye: 48 h & XTT: 24 h & XTT: $48 \mathrm{~h}$ \\
\hline SJCRH30 & $2.38 \pm 0.69 \mu \mathrm{M}$ & $1.79 \pm 0.45 \mu \mathrm{M}$ & $3.23 \pm 0.90 \mu \mathrm{M}$ & $2.04 \pm 0.07 \mu \mathrm{M}$ \\
\hline Neuro-2A & $2.80 \pm 0.91 \mu \mathrm{M}$ & $2.51 \pm 0.25 \mu \mathrm{M} *$ & $3.75 \pm 1.16 \mu \mathrm{M}$ & $3.93 \pm 1.07 \mu \mathrm{M} *$ \\
\hline $\begin{array}{l}\text { Neuro-2A }(25 \mu \mathrm{M} \\
\text { Veratridine, } 500 \mu \mathrm{M} \text { ouabain })\end{array}$ & $6.69 \pm 3.12 \mathrm{nM} *, \#$ & $6.61 \pm 1.29 \mathrm{nM} *, \#$ & $10.2 \pm 6.57 \mu \mathrm{M}$ & $2.85 \pm 1.18 \mu \mathrm{M}$ \\
\hline $\begin{array}{c}\text { Neuro-2A }(50 \mu \mathrm{M} \\
\text { Veratridine, } 500 \mu \mathrm{M} \text { ouabain })\end{array}$ & $2.79 \pm 1.24 \mathrm{nM} *, \#$ & $4.74 \pm 2.18 \mathrm{nM} *, \#$ & $0.73 \pm 1.20 \mu \mathrm{M} *, \#$ & $0.67 \pm 1.06 \mu \mathrm{M}^{\#}$ \\
\hline
\end{tabular}

Table 4. $\mathrm{EC}_{50}$ values for cytotoxicity of PbTx-2 on SJCRH30 and Neuro-2A cells as measured by the XTT and H-dye assays. * indicates significance from SHCRH30, and \# indicates significance from Neuro-2A (values in the same column).

\begin{tabular}{|c|c|c|c|c|}
\hline Cell Line & H-Dye: 24 h & H-Dye: 48 h & XTT: 24 h & XTT: $48 \mathrm{~h}$ \\
\hline SJCRH30 & $1.76 \pm 0.37 \mu \mathrm{M}$ & $0.52 \pm 0.09 \mu \mathrm{M}$ & $2.60 \pm 1.33 \mu \mathrm{M}$ & $1.10 \pm 0.97 \mu \mathrm{M}$ \\
\hline Neuro-2A & $2.09 \pm 0.65 \mu \mathrm{M}$ & $1.94 \pm 0.17 \mu \mathrm{M} *$ & $2.60 \pm 0.31 \mu \mathrm{M}$ & $2.83 \pm 0.69 \mu \mathrm{M}$ \\
\hline $\begin{array}{l}\text { Neuro-2A ( } 25 \mu \mathrm{M} \text { veratridine, } \\
500 \mu \mathrm{M} \text { ouabain })\end{array}$ & $2.40 \pm 1.80 \mu \mathrm{M}$ & $0.43 \pm 0.68 \mu \mathrm{M}^{\#}$ & $6.78 \pm 3.30 \mu \mathrm{M}$ & $5.49 \pm 0.90 \mu \mathrm{M} *$ \\
\hline $\begin{array}{l}\text { Neuro-2A ( } 50 \mu \mathrm{M} \text { veratridine, } \\
\qquad 500 \mu \mathrm{M} \text { ouabain })\end{array}$ & $20.6 \pm 6.23 \mathrm{nM} *, \#$ & $17.9 \pm 8.87 \mathrm{nM} *, \#$ & $1.59 \pm 1.41 \mu \mathrm{M}$ & $3.99 \pm 3.61 \mu \mathrm{M}$ \\
\hline
\end{tabular}

When ouabain and veratridine were added to the Neuro-2A cell cytotoxicity assay, several factors were observed (Tables 3 and 4). First, there was an increase in sensitivity to PbTxs, although the variability greatly increased, as demonstrated by the large standard deviations for the $\mathrm{EC}_{50}$ values. Second, the XTT assay did not always detect this increase in sensitivity. Neuro-2A cells treated with PbTxs, ouabain and $50 \mu \mathrm{M}$ veratridine showed sensitivity to PbTxs in the nanomolar range when assayed on the H-dye nuclear stain assay, but only the micromolar range when assayed on the XTT assay (Tables 3 and 4). Ouabain/veratridine-treated Neuro-2A cells did not show a typical sigmoidal dose response curve in response to PbTxs, but rather have a polynomial shaped curve, which made calculating $\mathrm{EC}_{50}$ values highly variable at both 24 and 48 h (48 h shown, Figures 3 and 4). This oddly shaped curve was observed in some XTT experiments, but not all, and not to the extreme that could be seen with the H-dye nuclear stain assay. Ouabain/veratridine-treated Neuro-2A cells appeared to show an initial cytotoxicity to PbTxs at $0.1 \mu \mathrm{M}$, with recovery around $1 \mu \mathrm{M}$ and nearly complete toxicity at $10 \mu \mathrm{M}$. The percentage of cell death at initial cytotoxicity varied according to the PbTx used, with PbTx-1 yielding 20\%-30\% and PbTx-2 yielding 40\%-50\% cytotoxicity at $0.1 \mu \mathrm{M}$ (Figures 3 and 4 ). The variation in $\mathrm{EC}_{50}$ values observed within the experiments of this study and, between experiments of the literature, could be explained by the highest concentration used to calculate $\mathrm{EC}_{50}$ values from corresponding sigmoidal dose response curves. If studies only used up to $0.1 \mu \mathrm{M} \mathrm{PbTx}$, rather than the highest $10 \mu \mathrm{M}$ dose used in this study, then complete cytotoxicity might not have been obtained. Furthermore, the traditional MTT or XTT assay might not even be able to detect the recovery seen at $1 \mu \mathrm{M}$, as the XTT assay was not as sensitive as the H-dye nuclear stain assay in our study. 
Figure 3. Cytotoxicity and apoptosis assay curves of cells treated with $\mathrm{PbTx}-1$ for $48 \mathrm{~h}$. (A-D) (purple open circle) the cytotoxicity assay as measured by fluorescent nuclear stain. $(\mathbf{E}-\mathbf{H})$ The apoptosis assay for apoptosis as measured by Annexin V staining (green triangle), necrosis as measured by Annexin V/PI co-staining (red square) and healthy cells as measured by no staining (blue circle). Each point represents the mean \pm standard deviation for $n=3-5$ experiments.
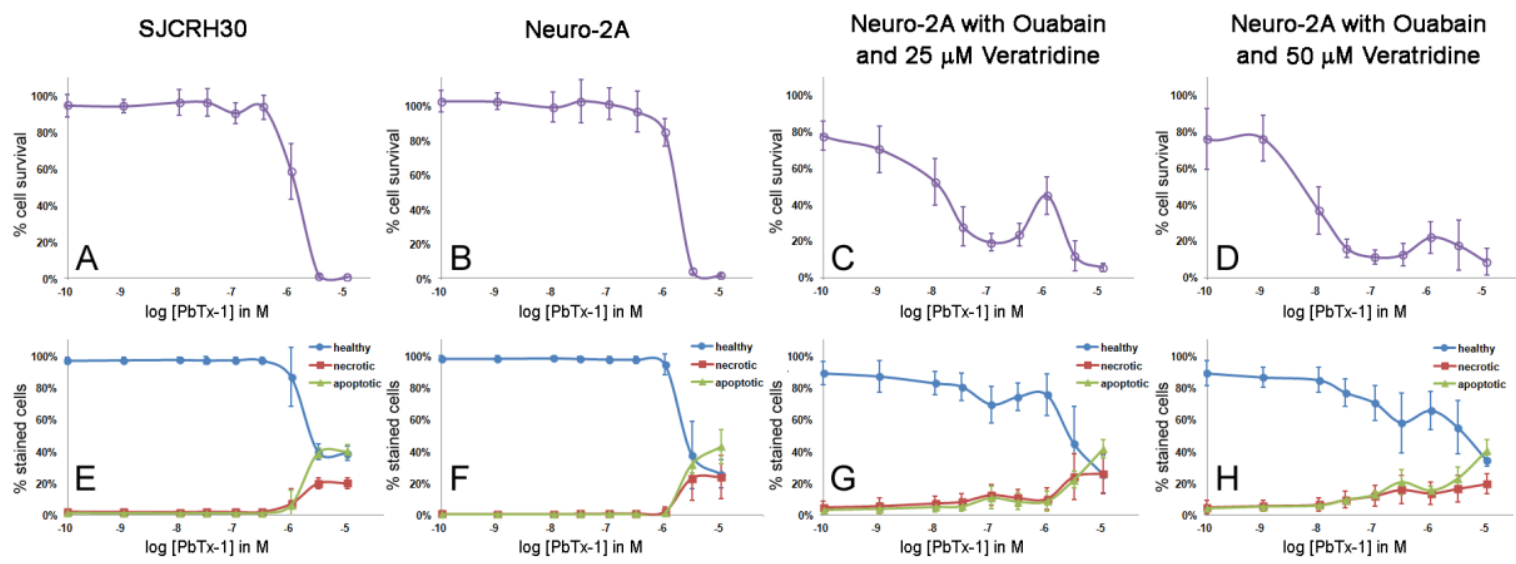

Figure 4. Cytotoxicity and apoptosis assay curves of cells treated with $\mathrm{PbTx}-2$ for $48 \mathrm{~h}$. (A-D) (purple open circle) the cytotoxicity assay as measured by fluorescent nuclear stain. $(\mathbf{E}-\mathbf{H})$ The apoptosis assay for apoptosis as measured by Annexin V staining (green triangle), necrosis as measured by Annexin V/PI co-staining (red square) and healthy cells as measured by no staining (blue circle). Each point represents the mean \pm standard deviation for $n=3-5$ experiments.
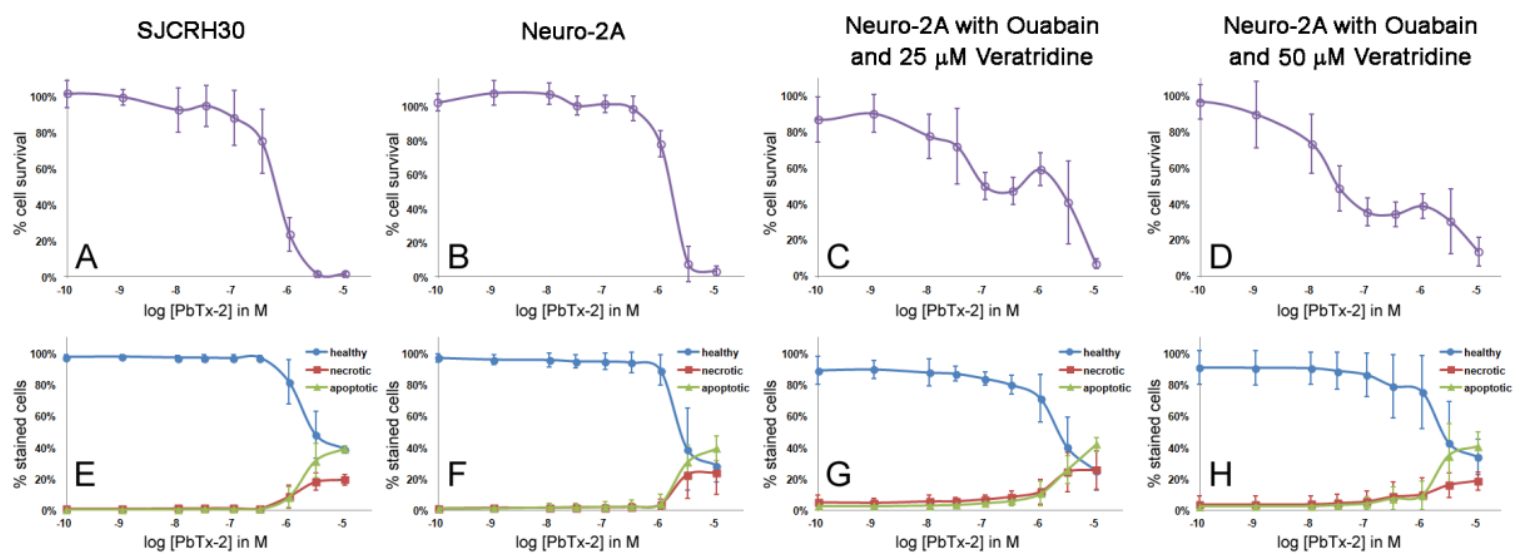

\subsection{Apoptosis/Necrosis Effects of PbTx and/or Ouabain and Veratridine}

To investigate the causes of the cytotoxicity recovery seen at $1 \mu \mathrm{M}$ PbTx, SJCRH30 and Neuro-2A (with and without ouabain and veratridine) were stained with Annexin V and propidium iodide (PI). Annexin $\mathrm{V}$ is a protein that transitions to the outside of cell membranes during apoptosis. Cells stained for Annexin V only are considered apoptotic. Cells stained for both Annexin V and PI are considered necrotic, as the cell membranes become permeable during necrosis and the stains can enter the cell [32,33]. 
Without the presence of ouabain and veratridine, apoptosis and necrosis events were low for both SJCRH30 and Neuro-2A cells in the presence of PbTx-1 or PbTx-2 until concentrations of 5-10 $\mu \mathrm{M}$ (Figures 3E,F and 4E,F). Apoptosis was significantly higher than necrosis for SJCHR30 cells with $5 \mu \mathrm{M} \mathrm{PbTx}-1$ and $10 \mu \mathrm{M} \mathrm{PbTx}-1$ and PbTx-2. The increase in apoptosis and necrosis for SJCRH30 and Neuro-2A cells at 5-10 $\mu \mathrm{M}$ PbTxs corresponded to the same dose at which the cytotoxicity assay measured $0 \%$ cell survival (Figures $3 \mathrm{~A}, \mathrm{~B}$ and $4 \mathrm{~A}, \mathrm{~B}$ ).

With the presence of ouabain and veratridine, Neuro-2A cells exhibited an initial decline in cell survival, followed by recovery at $1 \mu \mathrm{M}$ PbTxs and, then, a second decline in cells survival to the maximal dose of PbTxs (Figures 3C,D and 4C,D). Similar triphasic response patterns in cytotoxicity were also seen at $24 \mathrm{~h}$ treatment (data not shown). Apoptosis and necrosis events were higher (3\%-4\%) in ouabain and veratridine-treated cells than untreated cells $(0 \%-1 \%)$ at low to zero presence of PbTxs, likely due to the presence of these neurotoxins. Apoptosis and necrosis in ouabain, veratridine and $\mathrm{PbTx}$-treated cells increased slightly around $0.1 \mu \mathrm{M}$ PbTxs before declining again at $1 \mu \mathrm{M}$, corresponding to the dose of initial decline and recovery in cell survival exhibited in cytotoxicity assays. This effect was seen most obviously at $50 \mu \mathrm{M}$ veratridine and $\mathrm{PbTx}-1$ treatment (Figure $3 \mathrm{H}$ ). While not in perfect alignment with the cytotoxicity assay, the results of the apoptosis assay indicate that some cellular factor(s) may be reducing apoptosis and/or necrosis in Neuro-2A cells treated with ouabain, veratridine and $\mathrm{PbT}$ xs around a $1-\mu \mathrm{M}$ concentration.

Triphasic apoptotic responses, such as those seen in this study, have previously been documented in irradiated zebrafish embryos. Below a certain radioactive dose, there was an increase in apoptosis, with hormesis observed at an intermediate dose and increasing apoptosis at high doses above the hormetic dose range [34]. Biphasic hormesis responses to toxins are well known, where high doses are toxic and a low dose has a protective response by initiating detoxifying cellular machinery [35]. While we do not know at this point what causes the hormesis seen with $\mathrm{PbTx}$ exposure to ouabain/veratridine-treated Neuro-2A cells, it is likely due to the activation of detoxifying protective systems within the cells. The width of the hormetic dose range in toxicology is typically less than 100 -fold in dose [36], which is consistent with PbTx hormesis in our study.

\subsection{Cell Morphology of SJCRH30 and Neuro-2A Cell Lines}

In addition to the increased efficiency and sensitivity of live cell counting associated with the H-dye nuclear stain assay, the microscopy method is also able to detect other morphological parameters of cell lines depending on what parts of the cell are stained fluorescently. As shown in Figure 5, cells can be visually seen in decreasing numbers as PbTx-2 concentrations increased. In addition, the SJCRH30 cells are most observant in changing shape, with a less spread out morphology (indicated by less tubulin) by $1000 \mathrm{nM} \mathrm{PbTx}-2$. The lower sensitivity of Neuro2A cells to PbTx-2 as compared to SJCRH30 cells, reflected in the higher $\mathrm{EC}_{50}$ values of Table 4, can be visually seen in Figure 5. In addition, the morphological changes effected by ouabain and veratridine, in addition to the decrease in live cells, due to ouabain and veratridine (reflected by Table 2), can also be seen by the fluorescence microscopy assay (Figure 5). 
Figure 5. Cell morphology at increasing doses of PbTx-2 after $48 \mathrm{~h}$. Cells were stained with Hoechst 33342 nuclear dye (blue) and Tubulin Tracker (green). A representative experiment is shown.

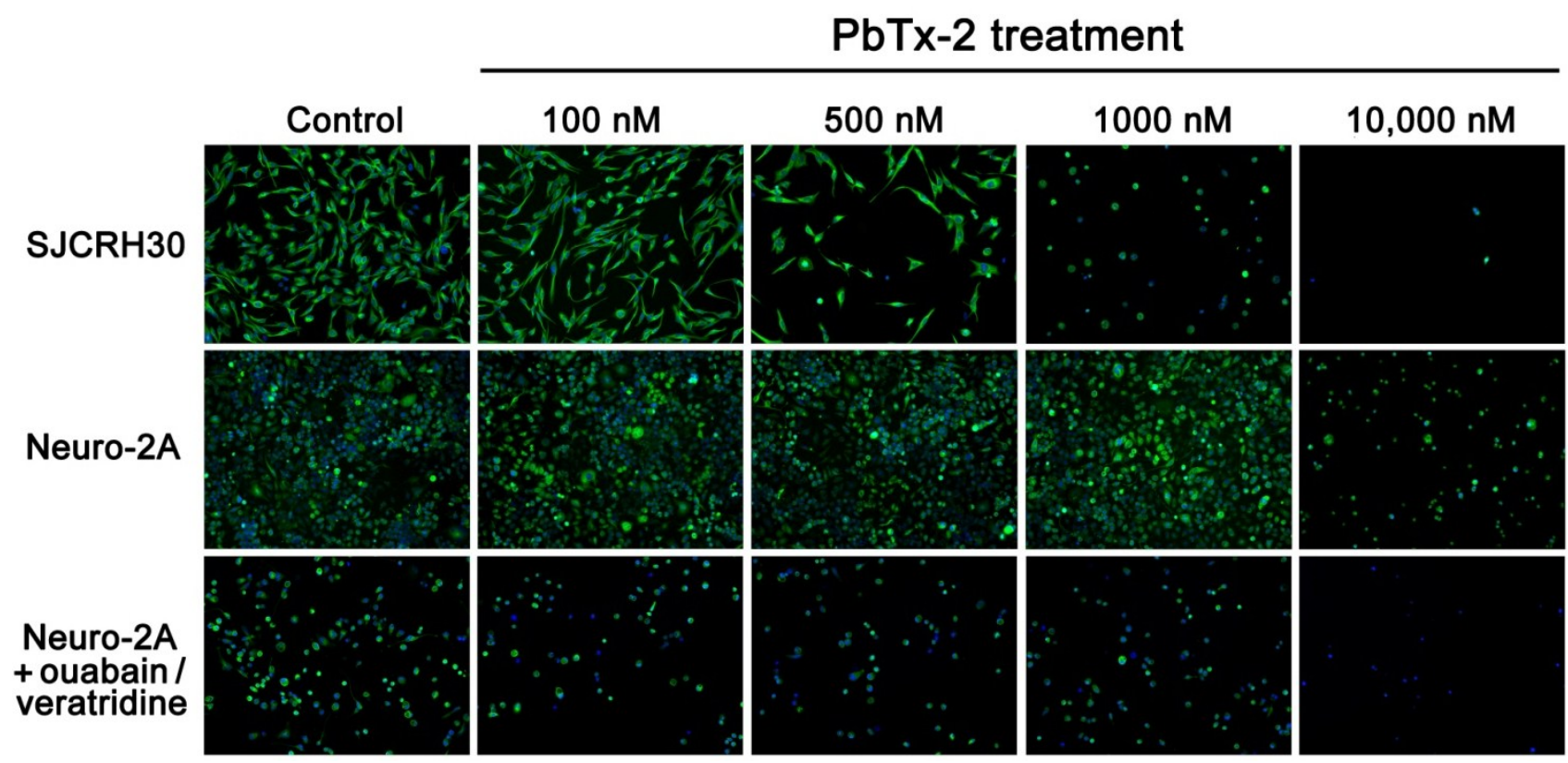

The Image Xpress Micro and corresponding MetaXpress Image Acquisition and Analysis software (Molecular Devices, Sunnyvale, CA, USA) are also able to calculate several morphological parameters of cells in the cytotoxicity assay. Using the SJCRH30 cell images obtained in Figure 5, average cell area, nuclear area and tubulin area, as well as the percentage of cells with tubulin were calculated and reported in Table 5, along with the cell counts that are used for calculating cytotoxicity curves. This is a representative example of what can be calculated along with cytotoxicity to gain a greater understanding of the effects of PbTxs during cytotoxicity. As shown in Table 5, not only does cell count decrease with increasing concentrations of PbTx-2, but so does the percentage of cells with tubulin, cell area and tubulin area. Both tubulin area and cell area show an increase around $500 \mathrm{nM}$, indicating cell swelling. This occurs at the concentration corresponding to right before Annexin-V staining (an early indicator of apoptosis) begins to increase in SJCRH30 cells (Figure 4). Interestingly, nuclear area does not decrease with increasing concentrations of PbTx-2 (Table 5).

Table 5. SJCRH30 cell morphology data from Figure 5.

\begin{tabular}{cccccc}
\hline [PbTx-2] & Cell Count & Cell Area & Nuclear Area & \% Cells with Tubulin & Tubulin Area \\
\hline 0 & 289 & 637.8 & 203.0 & $95.1 \%$ & 621.1 \\
$100 \mathrm{nM}$ & 234 & 681.2 & 209.7 & $98.3 \%$ & 674.6 \\
$500 \mathrm{nM}$ & 74 & 908.6 & 258.7 & $94.6 \%$ & 899.2 \\
$1000 \mathrm{nM}$ & 50 & 367.1 & 222.4 & $74.0 \%$ & 331.5 \\
$10,000 \mathrm{nM}$ & 3 & 352.5 & 251.7 & $66.7 \%$ & 290.1 \\
\hline
\end{tabular}




\section{Experimental Section}

$\mathrm{PbTx}-1$ and $\mathrm{PbTx}-2$ were extracted and purified from K. brevis (Wilson strain) unialgal cultures, as previously described [37-39]. Ouabain and veratridine were purchased from Sigma-Aldrich (St. Louis, MO, USA). CELLCOAT poly-D-lysine 96-well tissue culture plates were purchased from Greiner BioOne (Monroe, NC, USA). Phosphate buffered saline (PBS), Hanks Buffer Saline Solution (HBSS), penicillin, streptomycin, fetal bovine serum (FBS), horse serum, Tubulin Tracker 488, Hoechst 33342 (H-dye), Annexin-V-Alexa Fluor 488 and propidium iodide were purchased from Invitrogen Life Technologies (Grand Isle, NY, USA).

The B35 (CRL-2754), BE(2)-M17 (CRL-2267), Neuro-2A (CCL-131), PC-12 (CRL-1721), SH-SY5Y (CRL-2266) and SJCRH30 (CRL-2061) cell lines were purchased from ATCC (Manassas, VA, USA). The B50 cell line was purchased from Sigma-Aldrich (St. Louis, MO, USA). All cell lines were seeded at 5000 cells per well in a 96-well plate, with the exception of PC-12 cells, which were seeded at 10,000 cells per well, because of their small size. B35 and B50 cells were cultured in DMEM with GlutaMAX (Invitrogen Life Technologies, Grand Isle, NY, USA) containing 10\% FBS. BE(2)-M17 and SH-SY5Y cells were cultured in EMEM/F12K (1:1) (ATCC, Manassas, VA, USA) containing 10\% FBS. Neuro-2A cells were cultured in EMEM (ATCC, Manassas, VA, USA) containing 10\% FBS. SJCRH30 cells were cultured in RPMI (ATCC, Manassas, VA, USA) containing 10\% FBS. PC12 cells were cultured in RPMI containing 10\% horse serum and 5\% FBS (ATCC, Manassas, VA, USA). All cells were incubated at $37{ }^{\circ} \mathrm{C}$ for $24 \mathrm{~h}$ prior to treatment. Cells were then treated with PbTx-1 or PbTx-2 $(0.1 \mathrm{nM}$ to $30 \mu \mathrm{M})$. A subset of cells were also treated with ouabain $(500 \mu \mathrm{M})$ and veratridine $(25 \mu \mathrm{M}$ or $50 \mu \mathrm{M})$ at the same times as PbTx treatment. Following 24-72 h of treatment, cells were assayed for cytotoxicity or apoptosis activity.

Cytotoxicity was measured using fluorescence staining of cell nuclei. At the time of the treatment described above, control and treated cell nuclei were stained with $0.1 \mu \mathrm{g} / \mathrm{mL}$ Hoechst 33342 (H-dye) in PBS. Following 24-72 h of treatment, non-adherent cells were removed with the media, and adherent cells were washed with $200 \mu \mathrm{L}$ pre-warmed HBSS per well. Cells were then stained with $200 \mathrm{nM}$ Tubulin Tracker 488 in HBSS at $37{ }^{\circ} \mathrm{C}$ for $20 \mathrm{~min}$. The intensity of fluorescence of the H-dye stain was measured on the DAPI channel of the Image Xpress Micro (Molecular Devices, Sunnyvale, CA, USA) using the MetaXpress Image Acquisition and Analysis v2.0.1.44 software (Molecular Devices, Sunnyvale, CA, USA). The percentage of positively-stained cells as compared to control treatments (percentage of maximum) averaged within 4 snapshots of each well were calculated with SAS v9.1.3 software (SAS Institute Inc., Cary, NC, USA) and analyzed with non-linear regression curve-fit analysis by GraphPad Prism v4.03 (San Diego, CA, USA) to yield EC50 values. In addition, pictures of cells from the cytotoxicity experiments stained with $\mathrm{H}$-dye and Tubulin Tracker were visualized using the MetaXpress Image Acquisition and Analysis v2.0.1.44 software (Molecular Devices, Sunnyvale, CA, USA).

The XTT cell proliferation assay (kit from ATCC, Manassas, VA, USA) was performed according to instructions from the manufacturer. Activated-XTT solution was added $(50 \mu \mathrm{L})$ to each well, and the intensity of color was measured following $1 \mathrm{~h}$ of development with absorbance at $475 \mathrm{~nm}$ on the Flex Station III microplate reader (Molecular Devices, Sunnyvale, CA, USA) using the SoftMax Pro 5.2 software (Molecular Devices, Sunnyvale, CA, USA). A reference reading was taken at $660 \mathrm{~nm}$ to 
assess non-specific absorbance. The percentage of maximum curves were analyzed with non-linear regression curve-fit analysis by GraphPad Prism v4.03 (GraphPad Software, San Diego, CA, USA) to yield $\mathrm{EC}_{50}$ values.

Apoptosis and necrosis of cells was measured using fluorescence staining of Annexin V. $48 \mathrm{~h}$ post-treatment as described above, cells were stained with Annexin-V-Alexa Fluor 488 (Invitrogen Life Technologies, Grand Isle, NY, USA) and propidium iodide. The proportion of positive cells for each stain were measured on the Image Xpress Micro and analyzed with SAS v9.1.3 software (SAS Institute Inc, Cary, NC, USA).

$\mathrm{EC}_{50}$ values determined for the various experimental setups were compared using ANOVA SAS v9.1.3 software (SAS Institute Inc., Cary, NC, USA). In all experiments, results are presented as the mean $\pm \mathrm{SD}$ and were considered statistically significant if a $p$-value of less than 0.05 .

\section{Conclusions}

The traditional cytotoxicity assay for the detection of PbTxs uses the Neuro-2A cell line, which must first be treated with the neurotoxins, ouabain and veratridine, in order to become sensitive to PbTxs. However, we have demonstrated that a hormesis effect can be seen in this model due to a triphasic dose response to PbTx treatment on ouabain/veratridine-treated Neuro-2A cells at 24-48 h. The triphasic dose response yielded a polynomial shaped curve rather than the typical sigmoidal dose response curve, which made calculating $\mathrm{EC}_{50}$ values highly variable. Because of this, great care must be taken when using the ouabain/veratridine-treated Neuro-2A cytotoxicity model for testing samples for the presence of PbTxs.

In this study, we have described a new fluorescence microscopy method, which allows for accurate calculation of cytotoxicity via nuclear staining. This method allowed for the observation of the hormetic effects of PbTxs on ouabain/veratridine-treated Neuro-2A cells, which was largely overlooked with the traditionally used XTT method. In addition, the fluorescence microscopy method allows for additional measurement of other viability parameters depending on which aspect of the cell is stained. We propose using the SJCRH30 cell line as an alternative to Neuro-2A cells, because of the good sensitivity to PbTxs at $48 \mathrm{~h}$ without the need for ouabain or veratridine and because their large size allows for clear visualization of the cytotoxicity. It is important to note that testing with tissue extracts and other samples would be needed to ultimately determine the extent that this assay can be used to survey for PbTxs, and ongoing work in our laboratory is directed to this end.

\section{Acknowledgments}

Portions of this work were sponsored by Marine Biotechnology in North Carolina (MARBIONC), an economic development program located at the University of North Carolina Wilmington. Special thanks go to Susan Niven and Tanya Hogue for isolating the brevetoxins.

\section{Author Contributions}

J.R.M. conceived of the experiments and analyzed the data. E.A.E. ran the cellular staining (cytotoxicity and apoptosis) experiments. A.J.B. supervised the entire project. 


\section{Conflicts of Interest}

The authors declare no conflict of interest.

\section{References}

1. Baden, D.G.; Tomas, C.R. Variations in major toxin composition for six clones of Ptychodiscus brevis. Toxicon 1988, 26, 961-963.

2. Bossart, G.D.; Baden, D.G.; Ewing, R.Y.; Roberts, B.; Wright, S.D. Brevetoxicosis in manatees (Trichechus manatus latirostris) from the 1996 epizootic: Gross, histologic, and immunohistochemical features. Toxicol. Pathol. 1998, 26, 276-282.

3. Kreuder, C.; Mazet, J.A.; Bossart, G.D.; Carpender, T.E.; Holyoak, M.; Elie, M.S.; Wright, S.D. Clinicopathologic features of suspected brevetoxicosis in double-crested cormorants (Phalacrocorax auritus) along the Florida gulf coast. J. Zool. Wildl. Med. 2002, 33, 8-15.

4. Flewelling, L.J.; Naar, J.P.; Abbot, J.P.; Baden, D.G.; Barros, N.B.; Bossart, G.D.; Bottein, M.D.; Hammond, D.G.; Haubold, E.M.; Heil, C.A.; et al. Red tides and marine mammal mortalities: Unexpected brevetoxin vectors may account for deaths long after or remote from an algal bloom. Nature 2005, 435, 755-756.

5. Walsh, C.J.; Leggett, S.R.; Carter, B.J.; Colle, C. Effects of brevetoxin exposure on the immune system of loggerhead sea turtles. Aquat. Toxicol. 2010, 97, 293-303.

6. Jeglitsch, G.; Rein, K.; Baden, D.G.; Adams, D.G. Brevetoxin-3 (PbTx-3) and its derivatives modulate single tetrodotoxin-sensitive sodium channels in rat sensory neurons. J. Pharmacol. Exp. Ther. 1998, 284, 516-525.

7. Purkerson, S.L.; Baden, D.G.; Fieber, L.A. Brevetoxin modulates neuronal sodium cannels in two cell lines derived from rat brain. Neurotoxicology 1999, 6, 909-920.

8. Baden, D.G.; Bourdelais, A.J.; Jacocks, H.; Michelliza, S.; Naar, J. Natural and derivative brevetoxins: Historical background, multiplicity, and effects. Environ. Health Perspect. 2005, 113, 621-625.

9. Poli, M.A.; Musser, S.M.; Dickey, R.W.; Eilers, P.P.; Hall, S. Neurotoxic shellfish poisoning and brevetoxin metabolites: A case study from Florida. Toxicon 2000, 38, 981-993.

10. Watkins, S.; Reich, A.; Fleming, L.; Hammond, R. Neurotoxic shellfish poisoning. Mar. Drugs 2008, 6, 431-455.

11. Backer, L.C.; Fleming, L.E.; Rowan, A.; Cheng, Y.S.; Benson, J.; Pierce, R.H.; Zaias, J.; Bean, J.; Bossard, G.D.; Johnson, D.; et al. Recreational exposure to aerosolized brevetoxins during Florida red tide events. Harmful Algae 2003, 2, 19-28.

12. Kirkpatrick, B.; Fleming, L.E.; Backer, L.C.; Bean, J.A.; Tamer, R.; Kirkpatrick, G.; Kane, T.; Wanner, A.; Dalpra, D.; Reich, A.; et al. Environmental exposures to Florida red tides: Effects on emergency room respiratory diagnoses admissions. Harmful Algae 2006, 5, 526-533.

13. Fleming, L.E.; Kirkpatrick, B.; Backer, L.C.; Bean, J.A.; Wanner, A.; Reich, A.; Zaias, J.; Cheng, Y.S.; Pierce, R.; Naar, J.; et al. Aerosolized red-tide toxins (brevetoxins) and asthma. Chest 2007, 131, 187-194. 
14. Dickey, R.; Jester, E.; Granade, R.; Mowdy, D.; Moncreiff, C.; Rebarchik, D.; Robl, M.; Musser, S.; Poli, M. Monitoring Brevetoxins During a Gymnodinium Breve Red Tide: Comparison of Sodium Channel Specific Cytotoxicity Assay and Mouse Bioassay for Determination of Neurotoxic Shellfish Toxins in Shellfish Extracts. Nat. Toxins 1999, 7, 157-165.

15. US Food and Drug Administration. Fish and Fisheries Products Hazards and Control Guide, 4th ed.; Center for Food Safety and Applied Nutrition, US Food and Drug Administration: Rockville, MD, USA, 2011.

16. FAO Food and Nutrition Paper 80. Marine Biotoxins; Food and Agriculture Organization of the United Nations: Rome, Italy, 2004.

17. Poli, M.A.; Mende, T.J.; Baden, D.G. Brevetoxins, unique activators of voltage-sensitive sodium channels, bind to specific sites in rat brain synaptosomes. Mol. Pharmacol. 1986, 30, 129-135.

18. Worrell, C.; Xiao, N.; Vidal, J.E.; Chen, L.; Zhong, B.; Remais, R. Field detection of Schistosoma japonicum cercariae in environmental water samples by quantitative PCR. Appl. Environ. Microbiol. 2011, 77, 2192-2195.

19. Kogure, K.; Tamplin, M.L.; Simidu, U.; Colwell, R.R. A tissue culture assay for tetrodotoxin, saxitoxin and related toxins. Toxicon 1988, 26, 191-197.

20. Jellett, J.F.; Marks, L.J.; Stewart, J.E.; Dorey, M.L.; Watson-Wright, W.; Lawrence, J.F. Paralytic shellfish poison (saxitoxin family) bioassays: Automated endpoint determination and standardization of the in vitro tissue culture bioassay, and comparison with the standard mouse bioassay. Toxicon 1992, 30, 1146-1156.

21. Manger, R.L.; Leja, L.S.; Lee, S.Y.; Hungerford, J.M.; Wekell, M.M. Tetrazolium-based cell bioassay for neurotoxins active on voltage-sensitive sodium channels: Semiautomated assay for saxitoxins, brevetoxins, and ciguatoxins. Anal. Biochem. 1993, 214, 190-194.

22. Manger, R.L.; Leja, L.S.; Lee, S.Y.; Hungerford, J.M.; Hokama, Y.; Dickey, R.W.; Granade, H.R.; Lewins, R.; Yasumoto, T.; Wekell, M.M. Detection of sodium channel toxins: Directed cytotoxicity assay of purified ciguatoxins, brevetoxins, saxitoxins, and seafood extracts. J. AOAC Int. 1995, 78, 521-527.

23. Abraham, A.; Plakas, S.M.; Wang, Z.; Jester, E.L.E.; El Said, K.R.; Granade, H.R.; Henry, M.S.; Blum, P.C.; Pierce, R.H.; Dickey, R.W. Characterization of polar brevetoxin derivatives isolated from Karenia brevis cultures and natural blooms. Toxicon 2006, 48, 104-115.

24. Twiner, M.J.; Bottein Dechraoui, M.Y.; Wang, Z.; Mikulski, C.M.; Henry, M.S.; Pierce, R.H.; Doucette, G.J. Extraction and analysis of lipophilic brevetoxins from the red tide dinoflagellate Karenia brevis. Anal. Biochem. 2007, 369, 128-135.

25. Truman, P. A cellular target for the lipophilic toxins from Karenia brevisulcata. Toxicon 2007, $50,251-255$.

26. Roth, P.B.; Twiner, M.J.; Wang, Z.; Bottein Dechraoui, M.Y.; Doucette, G.J. Fate and distribution of brevetoxin ( $\mathrm{PbTx}$ ) following lysis of Karenia brevis by algicidal bacteria, including analysis of open A-ring derivatives. Toxicon 2007, 50, 1175-1191.

27. Bottein Dechraoui, M.Y.; Fuquay, J.M.; Munday, R.; Selwood, A.I.; van Ginkel, R.; Miles, C.O.; Loader, J.I.; Wilkins, A.L.; Ramsdell, J.S. Bioassay methods for detection of $\mathrm{N}$-palmitoylbrevetoxin-B2 (BTX-B4). Toxicon 2010, 55, 497-506. 
28. Bottein Dechraoui, M.Y.; Tiedeken, J.A.; Persad, R.; Wang, Z.; Granade, H.R.; Dickey, R.W.; Ramsdell, J.S. Use of two detection methods to discriminate ciguatoxins from brevetoxins: Application to great barracuda from Florida Keys. Toxicon 2005, 46, 261-270.

29. Fairey, E.R.; Edmunds, J.S.G.; Ramsdell, J.S. A cell-based assay for brevetoxins, saxitoxins, and ciguatoxins usaing a stably expressed c-fos-luciferase reporter gene. Anal. Biochem. 1997, 251, 129-132.

30. Dechraoui, M.Y.; Naar, J.; Pauillac, S.; Legrand, A.M. Ciguatoxins and brevetoxins, neurotoxic polyether compounds active on sodium channels. Toxicon 1999, 37, 125-143.

31. Fairey, E.R.; Bottein Dechraoui, M.Y.; Sheets, M.F.; Ramsdell, J.S. Modification of the cell based assay for brevetoxins using human cardiac voltage dependent sodium channels expressed in HEK-293 cells. Biosen. Bioelectron. 2001, 16, 579-586.

32. Koopman, G.; Reutelingsperger, C.P.; Kuijten, G.A.; Keehnen, R.M.; Pals, S.T.; van Oers, M.H. Annexin $\mathrm{V}$ for flow cytometric detection of phosphatidylserine expression on B cells undergoing apoptosis. Blood 1994, 84, 1415-1420.

33. Vermes, I.; Haanen,C.; Steffens-Nakken, H.; Reutelingsperger, C. A novel assay for apoptosis. Flow cytometric detection of phosphatidylserine expression on early apoptotic cells using fluorescein labelled Annexin V. J. Immunol. Methods 1995, 184, 39-51.

34. Choi, V.W.Y.; Yum, E.H.W.; Konishi, T.; Oikawa, M.; Cheng, S.H.; Yu, K.N. Triphasic Low-dose response in zebrafish embryos irradiated by microbean protons. J. Radiat. Res. 2012 , 53, 475-481.

35. Calabrese, E.J. Hormesis: A revolution in toxicology, risk assessment and medicine. EMBO Rep. 2004, 5, S37-S40.

36. Calabrese, E.J.; Blain, R. The occurrence of hormetic dose responses in the toxicological literature, the hormesis database: An overview. Toxicol. Appl. Pharmacol. 2005, 202, 289-301.

37. Bourdelais, A.J.; Campbell, S.; Jacocks, H.; Naar, J.; Wright, J.L.C.; Carsi, J.; Baden, D.G. Brevenal is a natural inhibitor of brevetoxin action in sodium channel receptor binding assays. Cell. Mol. Neurobiol. 2004, 24, 553-563.

38. Truxal, L.T.; Bourdelais, A.J.; Jacocks, H.; Abraham, W.M.; Baden, D.G. Characterization of Tamulamides A and B, polyethers isolated from the marine dinoflagellate Karenia brevis. J. Nat. Prod. 2010, 73, 536-540.

39. McCall, J.R.; Jacocks, H.M.; Baden, D.G.; Bourdelais, A.J. Development of a competitive fluorescence-based synaptosome binding assay for brevetoxins. Harmful Algae 2012, 19, 85-91.

(C) 2014 by the authors; licensee MDPI, Basel, Switzerland. This article is an open access article distributed under the terms and conditions of the Creative Commons Attribution license (http://creativecommons.org/licenses/by/3.0/). 